\title{
Body part categorisation in Punjabi
}

\author{
Asifa Majid \\ Max Planck Institute for Psycholinguistics, Postbus 310, 6500 AH Nijmegen, The Netherlands
}

\begin{abstract}
A key question in categorisation is to what extent people categorise in the same way, or differently. This paper examines categorisation of the body in Punjabi, an Indo-European language spoken in Pakistan and India. First, an inventory of body part terms is presented, illustrating how Punjabi speakers segment and categorise the body. There are some noteworthy terms in the inventory, which illustrate categories in Punjabi that are unusual when compared to other languages presented in this volume. Second, Punjabi speakers' conceptualisation of the relationship between body parts is explored. While some body part terms are viewed as being partonomically related, others are viewed as being in a locative relationship. It is suggested that there may be key ways in which languages differ in both the categorisation of the body into parts, and in how these parts are related to one another.

(C) 2005 Elsevier Ltd. All rights reserved.
\end{abstract}

Keywords: Punjabi; Indo-European; Body part terms; Partonomy; Meronymy; Semantic fields

\section{Introduction}

How people categorise the world is one of the fundamental issues faced by researchers in linguistics, psychology, anthropology, and cognitive science. Is categorisation the same between individuals, either as a result of innate concepts, or regularities in the perceptual array? Or, is human categorisation arbitrary - a matter of cultural or linguistic convention? This paper examines the categorisation of parts of the body in Punjabi, an Indo-European language spoken in Pakistan and India, as a first step in addressing these questions in one domain.

E-mail address: Asifa.Majid@mpi.nl 
The human body is particularly interesting when trying to understand the relative impact of universal versus culture specific principles of categorisation. Unlike many other objects, the body is the same around the world (not withstanding population differences in colour, height and width, e.g. Ruff, 2002). So, we might expect that categories for parts of the body would be the same everywhere. But Punjabi speakers show some interesting differences in how parts of the body are categorised in comparison with other languages in this volume, suggesting that body part categorisation is not universal.

Punjabi speakers' body part categorisation was investigated by eliciting an inventory of body part terms. Each term that is used to refer to a body part designates a category (Brown, 1958). By comparing the terms that languages have for referring to body parts, we can see how similar or different languages are to one another. If body part categorisation is primarily the result of innate concepts, or regularities in the world such as perceptual boundaries, then we might expect that all languages will use the same inventory of words to refer to the body; on the other hand, if body part categorisation is a matter of cultural or linguistic convention, then body part lexicons in different languages may be very different to one another. Punjabi has a body part lexicon which seems very similar to English, for example, suggesting shared categorisation, however, there are some unusual categories too, suggesting a role for cultural convention. For example, in Punjabi the tip of the nose (nəkk di komli ${ }^{1}$ ) and the earlobe (kann di komli) are categorised together by the word komli (see Section 4.2). Similarly, there are a number of terms used to refer to various configurations of the hand (see Section 4.4). And more intriguingly, there is a category of internal body part which has no anatomical correlate (Section 4.3).

One noticeable aspect of terminology for parts of the body in Punjabi, compared to other languages in this volume, is the use of multiple forms for the same part of the body. These terms seem to share the same extensional range, and do not appear to differ in register, or style, for example mukhRa, buttha, and mũũ are all terms for 'face'. The use of multiple terms is probably a function of the pervasive multidialectalism of Punjabi speakers (Bhatia, 1993), which is discussed more in the next section.

\section{Punjabi and its speakers}

Punjabi originates from the Punjab province, which is divided between present day Pakistan and India. There are approximately 66 million speakers of Punjabi in Pakistan and 28 million in India, with additional speakers of the language in Malaysia, Singapore, United Kingdom, United Arab Emirates, Dubai, Canada and elsewhere.

There are a number of regional and social varieties of the language. Punjabi is an IndoAryan language comprised of many dialects, and there is a chain of such dialects blending to Hindi-Urdu. The present day status of these dialects is complex due to massive migration during the partition of Pakistan and India in 1947. Over 10 million people were uprooted and resettled at this time, adding further to the complexity of the linguistic situation.

The present investigation was conducted primarily with speakers from the Pakistani village of Boot Singh, located south of the city Kasur and east of Chunian. It is approxi-

\footnotetext{
${ }^{1}$ See Appendices A and B for the orthographic conventions.
} 
mately 10-15 miles from the Pakistani-Indian border. The speakers were originally located in, or are the descendents of speakers from Nakodar in the Jallandar province in present day India. Speakers of the Jallandar province are classified as speaking Doab Punjabi by Grierson (1916/1968). However, classification of the current speakers is difficult due to contact with other dialects and languages over the last 50 odd years. There is still very little documentation of the dialects of Punjabi (Tolstaya, 1981; Bhatia, 1993), so the similarities and differences between dialects is largely unknown. As well as speaking Punjabi, older consultants have passive knowledge of Hindi and Urdu. The younger consultants are all multilingual, speaking Urdu more or less fluently, and also have some limited competence in English, which they are taught at school.

Terms for body parts were collected using an elicitation questionnaire (Enfield, this volume a) and the extensional range of some of these body parts was tested using the 'body colouring task' (van Staden and Majid, this volume) where consultants have to colour in body parts on a line drawing of the human body. Data was collected from a number of consultants from a wide age range: one 80+-year-old woman, two 60+-year-old men, two 40-50-year-old women, four 15-25-year-old women, five 15-22-year-old men, one 6 -year-old girl, and two 4-year-old girls. Additional data was collected from two 4560-year-old women in Lahore.

\section{Structural properties of Punjabi body part terms}

Punjabi has a distinction between alienable and inalienable possession, as well as temporary and permanent possession, and whether the possessor is animate or inanimate. Body parts are inalienably possessed and expressed using genitive case marking $d a / d e /$ di/diã. This contrasts with the expression of alienable possessions (such as concrete objects) which are expressed through genitive case marking plus the postposition kol (near). Case marking agrees with the object, i.e. with the possessed term, in gender, number and case, as is shown in Examples (1) and (2) (for more details of possessive constructions in Punjabi, see Bhatia, 1993, pp. 146-147).

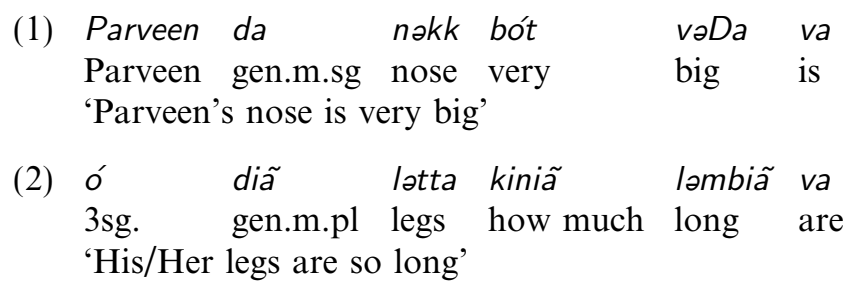

There are two grammatical genders in Punjabi: masculine and feminine. The body part lexicon appears to be equally divided into masculine and feminine nouns. Where a body part term freely occurs with either the masculine or the feminine form (e.g. bUttha, butthi, 'face'; khopRa, khopRi, 'scalp, skull, mind'; Iən, luli, 'penis') then both are given in the relevant table. This gender variation is most likely due to the fact that these body parts are sensitive to size, and the masculine gender represents a bigger size (both actual and speaker's perception) than the feminine.

Nouns are singular or plural in number. Most of the body part lexicon is inherently singular, with the exception of the hair terms val 'hair on head' and lũu' 'downy hair on body'. Note, though, that there are other hair terms which are singular, like tola 'white hair' and 
daRi 'beard'. PərvəTa 'eyebrows', pəlka 'eyelashes', muccha 'moustache', and kəlləm 'sideburn' are collective nouns. As well as the various hair terms, nasa 'nostrils' and bUII 'lips' are also plural.

\section{The inventory of body part terms}

Body part terms in Punjabi are all nouns. In order to establish body parts at least two different types of criteria can be used. The first is to establish whether a particular term is part-of the body (e.g. Cruse, 1986, 2004); the second is to use the possessive construction, so that if the nose is possessed-by the body, then it is a part of the body (e.g. Brown, 1976). Because of the problems of establishing whether a part-of relation is encoded by the possessive construction (see Section 5 for further discussion of this), consultants were first asked to list the parts of the body, followed by more specific questions about each body part.

There are a number of different terms that Punjabi speakers use to refer to the 'body' itself: jısm, pınDa, bədən, and shərir (see Section 4.2 for more detailed discussion of these terms). The commonest way to refer to the 'body' is jism. To establish parts of the body consultants were asked:

(3)

jısm de keRe keRe hisse va?
body gen.m.pl which which parts is
'What are the parts of the body?'

This construction with the reduplicative form of "which" involves a distributive or listing meaning (Bhatia, 1993), inviting consultants to offer a list of parts of the body. Additional elicitation to check the acceptance of body part terms offered by one consultant with a different consultant, and to check whether other nouns in the semantic domain of the body (e.g. snot, urine) were "body parts" was done by asking:

$X$ jism da hissa va?
$\mathrm{X}$ body gen.m.sg part is
'Is X a part of the body?'

Consultants offered some terms in response to the listing question which they later identified as not being Punjabi terms; instead they suggested that they were Urdu words. These terms have been included in this paper if more than one consultant used the term during the questionnaire elicitation task, on the grounds that they form part of the everyday vocabulary of the consultants. They are marked as Hindi-Urdu loans in the tables, as consultants were adamant that these were not "pure" Punjabi words. All of these words, in fact, derive from Indic (Hindi/Sanskrit) sources, apart from khũn and dimag which come from Perso-Arabic sources.

One hundred and fifty one body part terms were elicited using this procedure. ${ }^{2}$ Of these 151 terms almost all are simplex, i.e. monomorphemic and everyday expressions (not technical or specialist vocabulary, as used say by doctors or anatomists); only 15 are complex (see Enfield et al., this volume). Complex body part terms predominantly occur in the

\footnotetext{
${ }^{2}$ This number does not include terms for body configurations (of which there are 10, see Section 4.4), specialised terms for animal body parts (15, see Section 4.6), or other terms which are part of the semantic domain of the body, but not body parts proper (26, Section 4.5$)$.
} 
genitive construction, and are discussed further in Section 5. Given that most body parts are encoded by a simplex expression, most body parts could be regarded as equally cognitively "basic" on the basis of linguistic encoding.

\subsection{Features of the face}

Mũũ, mukhRa, bUttha, butthi, and the Urdu word cehra are all used to refer to the 'face'. The terms are extensionally equivalent covering the oval-shaped area on the front of the head not including the neck or the ears. But the term mũu differs here in that it is ambiguous in reference between the whole 'face' and just the 'mouth' (see Wilkins, 1996, for the same polysemy in Tibeto-Burman). Despite its ambiguity and the lack of ambiguity associated with the other terms for face, mũũ is the common term used in everyday speech to refer to face. The term mukhRa was only known by the older speakers of this dialect; while cehra was only produced by the youngest speakers. This reflects the changing linguistic situation in Pakistani Punjabi at the moment. While older speakers may be multidialectal in Punjabi dialects, the younger speakers are moving away from speaking Punjabi to speaking Urdu. Urdu is the language of prestige and status. While the children are educated in Urdu, with an increasing emphasis on English, Punjabi can play a relatively small role in their day-to-day life.

Buttha (masculine) and butthi (feminine) are used with a negative connotation. Examples (5) and (6) give typical uses of these terms, i.e. they are used to refer to someone who is sulking or in a bad mood.

$\begin{array}{llll}o & \text { di } & \text { bUtthi } & \text { kidã } \\ \text { 3sg } & \text { gen.f.sg } & \text { face.f.sg } & \text { how }\end{array}$

'He/she is sulking/in a bad mood'

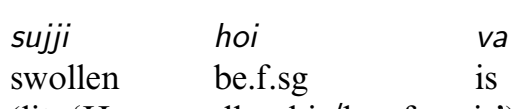

(lit. 'How swollen his/her face is')

$\begin{array}{lllll}\text { (6) Sajida } & \text { ne bUttha } & \text { phUlara } & \text { hoia } & \text { va } \\ \text { Sajida } & \text { erg. } & \text { face.m.sg } & \text { blown-up be.m.sg. } & \text { is } \\ \text { 'Sajida is sulking' } & & \text { (lit. 'Sajida's face is blown-up') }\end{array}$

Both the masculine and feminine terms can be used in either sentence. The use of the masculine indicates that the face is even bigger, and correspondingly that the emotional state of the person is more intense.

As with face, there is a number of terms for 'eye', $ə k k h, D i D D a$ and $n æ n ; ~ a k k h$ is the commonly used term, with DiDDa only known to the elder speakers, and the Hindi-Urdu term næn only used by the younger speakers. The 'pupil' is akkh da tara (lit. 'eye its star'). It is widely attested cross-linguistically that the pupil is referred to with a figurative expression, the most common one equating the pupil with a human being or human-like object (e.g. 'person of the eye', 'angel of the eye'); alternatively the pupil is equated with a seed or similar object (e.g. 'kernel', 'acorn') (Brown and Witkowski, 1981). Marshallese, an Austronesian language, was the only example that Brown and Witkowski (1981) found in a sample of 118 languages which equates the pupil with a star. To this sole example, we can add Punjabi, as well as Hindi and Urdu, as examples of languages which use the expression 'the star of the eye' to refer to the pupil.

All of the terms to refer to features of the face are monomorphemic, apart from $ə k k h d a$ tara 'pupil' and nakk di komli 'tip of the nose', which will be discussed in the next section. 
Table 1

Punjabi parts of the face

\begin{tabular}{|c|c|c|c|c|}
\hline Punjabi term & Translation & $\begin{array}{l}\text { Gender and } \\
\text { number }^{\mathrm{a}}\end{array}$ & & Other information \\
\hline \multicolumn{5}{|l|}{ Simplex } \\
\hline mũũ & 'mouth, face' & $\mathrm{m}$ & & \\
\hline mukhRa & 'face' & $\mathrm{m}$ & & \\
\hline bUttha & 'face' & $\mathrm{m}$ & & \\
\hline bUtthi & 'face' & $\mathrm{f}$ & & \\
\hline cehra & 'face' & $\mathrm{m}$ & & Hindi-Urdu loan \\
\hline mattha & 'forehead' & $\mathrm{m}$ & & \\
\hline porpəRi & 'temple' & $\mathrm{f}$ & & \\
\hline akkh & 'eye' & $\mathrm{f}$ & & \\
\hline$D i D D a$ & 'eye' & $\mathrm{m}$ & & \\
\hline$n æ n$ & 'eye' & $\mathrm{f}$ & & Hindi-Urdu loan \\
\hline Dælla & 'eyeball' & $\mathrm{m}$ & & \\
\hline pərvəTa & 'eyebrow' & $\mathrm{m}$ & & \\
\hline palkə & 'eyelashes' & $\mathrm{f}$ & & \\
\hline nakk & 'nose' & $\mathrm{m}$ & & \\
\hline nasa & 'nostrils' & $\mathrm{f}$ & $\mathrm{pl}$ & \\
\hline$b U I I$ & 'lip' & $\mathrm{f}$ & $\mathrm{pl}$ & \\
\hline gəl & 'cheek' & $\mathrm{f}$ & & \\
\hline cəbaRa & ‘jaw’ & $\mathrm{m}$ & & \\
\hline hərb & 'masseter' & $\mathrm{f}$ & & side of the jaw \\
\hline ThoDDi & 'chin' & $\mathrm{f}$ & & \\
\hline$d a R i$ & 'beard' & $\mathrm{f}$ & & \\
\hline muccha & 'moustache' & $\mathrm{m}$ & & \\
\hline kəlləm & 'side-burn' & $\mathrm{f}$ & & \\
\hline \multicolumn{5}{|l|}{ Complex } \\
\hline akkh da tara & 'pupil' & $\mathrm{m}$ & & lit. 'eye its star' \\
\hline nakk di komli & 'tip of the nose' & $\mathrm{f}$ & & lit. 'nose its komli' \\
\hline
\end{tabular}

a In all tables, number is singular, unless otherwise specified.

The term for jaw, cəbaRa, although synchronically unanalysable, was likely historically derived from the verb $c ə b$ 'chew' plus the suffix - aRa, which is a productive device for forming agentive nouns, so cəbaRa is the 'chewer'. Younger speakers alternately use the forms cəbəRa or jəbəRa, the latter of which is the Hindi-Urdu form. Similar forms for jaw can be seen in French, mâchoire 'jaw' from mâcher 'chew'; and perhaps also English jaw which in Old English was chowe from céowan 'chew' (although the etymology for the latter terms is disputed, Buck, 1949) (Table 1).

\subsection{External parts}

As discussed previously, there are a number of ways to refer to the 'body' but the most commonly used term is jism. A distinction is made between the living body and the dead body, məiyət. Terms for left and right sides of the body are referred to as in English by adding the modifier left or right in front of the body part noun e.g. khabba hatth 'left hand', səjja hatth 'right hand'.

Multiple terms are also in use to refer to the neck and the back (Table 2). The forms $t$ on, gərdən, gaTi, gıcci and gı'TTi are all used to refer to the neck. Gıcci may have as its central 
Table 2

Punjabi external parts of the body

\begin{tabular}{|c|c|c|c|}
\hline Punjabi term & Translation & Gender and number & Other information \\
\hline \multicolumn{4}{|l|}{ Simplex } \\
\hline məiyət & 'corpse' & $\mathrm{f}$ & Hindi-Urdu loan \\
\hline bədən & 'body' & $\mathrm{m}$ & Hindi-Urdu loan \\
\hline jism & 'body' & $\mathrm{m}$ & \\
\hline pınDa & 'body' & $\mathrm{m}$ & \\
\hline sharir & 'body' & $\mathrm{m}$ & Hindi-Urdu loan \\
\hline jılt & 'skin’ & $\mathrm{m}$ & Hindi-Urdu loan \\
\hline$c ə m R a$ & 'skin' & $\mathrm{m}$ & \\
\hline val & 'hair' & $\mathrm{m}$ & \\
\hline tola & 'white hair' & $\mathrm{m}$ & \\
\hline Iũũ & 'downy hair' & $\mathrm{m}$ & \\
\hline khopRi & 'scalp, skull, mind' & $\mathrm{f}$ & \\
\hline khopRa & 'scalp, skull, mind' & $\mathrm{m}$ & \\
\hline sir & 'head' & $\mathrm{m}$ & \\
\hline kənn & 'ear’ & $\mathrm{m}$ & \\
\hline $\operatorname{ton}$ & 'neck' & $\mathrm{m}$ & \\
\hline gərdən & 'neck' & $\mathrm{f}$ & Hindi-Urdu loan \\
\hline gaTi & 'neck' & f & \\
\hline gicci & 'neck, nape of neck' & $\mathrm{f}$ & \\
\hline gíTTi & 'neck' & f & \\
\hline kala & 'Adam's apple' & $\mathrm{m}$ & \\
\hline kənda & 'shoulder' & $\mathrm{m}$ & \\
\hline$m o ́ D a$ & 'shoulder' & $\mathrm{m}$ & regio deltoidea \\
\hline pəTTha & 'shoulder muscles along the back' & $\mathrm{m}$ & \\
\hline TUi & 'back' & $\mathrm{f}$ & \\
\hline piTTh & 'back' & $\mathrm{f}$ & \\
\hline kəmər & 'back' & $\mathrm{f}$ & Hindi-Urdu loan \\
\hline$m \supset R$ & 'back-upper' & $\mathrm{m}$ & \\
\hline lək & 'back, lower back and waist' & $\mathrm{m}$ & \\
\hline$T ı k$ & 'back' & $\mathrm{m}$ & \\
\hline tUnni & 'navel' & $\mathrm{f}$ & \\
\hline dhun & 'navel (protruding)' & $\mathrm{m}$ & \\
\hline chati & 'chest/breast' & $\mathrm{f}$ & \\
\hline mummæ & 'breasts' & $\mathrm{f}$ & \\
\hline$p h U_{n} D D i$ & 'nipple' & $\mathrm{f}$ & \\
\hline peT & 'stomach' & $\mathrm{m}$ & Hindi-Urdu loan \\
\hline TiDD & 'stomach' & $\mathrm{m}$ & \\
\hline TiDDi & 'stomach’ & $\mathrm{f}$ & \\
\hline kUssi & 'vulva' & $\mathrm{f}$ & \\
\hline$p h U D D i$ & 'vulva' & $\mathrm{f}$ & \\
\hline Iuli & 'penis' & $\mathrm{f}$ & \\
\hline lan & 'penis' & $\mathrm{m}$ & \\
\hline təndua & 'foreskin' & $\mathrm{m}$ & \\
\hline$c u D D i$ & 'groin’ & $\mathrm{f}$ & \\
\hline TuTæ & 'testicles' & $\mathrm{m}$ & \\
\hline $\mathrm{cIt} R$ & 'hip, buttocks' & $\mathrm{f}$ & \\
\hline bunD & 'bottom' & $\mathrm{f}$ & \\
\hline$k ə c$ & 'armpit' & $\mathrm{f}$ & \\
\hline bəgal & 'armpit' & $\mathrm{m}$ & Hindi-Urdu loan \\
\hline bãã & 'arm' & $\mathrm{f}$ & \\
\hline bazu & 'arm' & $\mathrm{m}$ & $\begin{array}{l}\text { Hindi-Urdu loan } \\
\text { (continued on next page) }\end{array}$ \\
\hline
\end{tabular}


Table 2 (continued)

\begin{tabular}{|c|c|c|c|}
\hline Punjabi term & Translation & Gender and number & Other information \\
\hline DJlla & 'bicep, upper arm' & $\mathrm{m}$ & \\
\hline ərk & 'elbow' & $\mathrm{f}$ & \\
\hline kũni & 'elbow’ & $\mathrm{f}$ & \\
\hline væni & 'forearm' & $\mathrm{f}$ & \\
\hline gut & 'wrist' & $\mathrm{m}$ & \\
\hline hatth & 'hand' & $\mathrm{m}$ & \\
\hline gənDh & 'knuckle' & $\mathrm{f}$ & \\
\hline talli & 'palm' & $\mathrm{f}$ & \\
\hline tilli & 'palm' & f & \\
\hline hattheli & 'palm' & $\mathrm{f}$ & \\
\hline Ũygli & ‘finger' & $\mathrm{f}$ & also 'toe' \\
\hline cici & 'little finger' & $\mathrm{f}$ & \\
\hline anGuTha & 'thumb' & $\mathrm{m}$ & \\
\hline no & 'nail' & $\mathrm{m}$ & \\
\hline Taang & 'leg' & $\mathrm{f}$ & Hindi-Urdu loan \\
\hline latt & 'leg' & $f$ & \\
\hline paT & 'thigh' & $\mathrm{m}$ & \\
\hline$g o D D a$ & 'knee' & $\mathrm{m}$ & \\
\hline chəpni & 'knee cap' & $\mathrm{f}$ & \\
\hline pınni & 'calf, lower leg' & $\mathrm{f}$ & \\
\hline gıTTa & 'ankle' & $\mathrm{f}$ & \\
\hline pær & 'foot' & $\mathrm{m}$ & \\
\hline$p a b b$ & 'sole of foot' & $\mathrm{m}$ & \\
\hline əDDi & 'heel' & $f$ & \\
\hline \multicolumn{4}{|l|}{ Complex } \\
\hline bUga chHUtta & 'white hair' & $\mathrm{m}$ & \\
\hline kən di komli & 'ear lobe' & f & lit. 'ear its komli' \\
\hline phəphóndi danna & 'clitoris' & $\mathrm{f}$ & lit. 'phəphóndi grain-of' \\
\hline Ũggli da pذ̀Ta & 'finger-tip' & $\mathrm{m}$ & lit. 'finger its pذ̀Ta' \\
\hline pær di Ũngli & 'toe' & $f$ & \\
\hline pær da ə’GuTha & 'big toe' & $\mathrm{m}$ & lit. 'foot its thumb' \\
\hline pær di cici & 'little toe' & f & lit. 'foot its little finger' \\
\hline pær da pذ̀Ta & 'tip of toe' & $\mathrm{m}$ & lit. 'foot its $p \grave{\supset} T a$ ' \\
\hline pær di təlli & 'sole of foot' & $\mathrm{f}$ & lit. 'foot its palm' \\
\hline pær da Ũngli & 'toe' & $\mathrm{m}$ & lit. 'foot its finger' \\
\hline
\end{tabular}

meaning 'nape of the neck', although not all consultants agreed that this was the case. GaTi and gıcci were only produced by the older speakers. For both older and younger speakers ton and gərdən are the common terms used to refer to neck. There do not appear to be further distinctions in extension or differences in register between these words.

There are two terms to refer to the 'shoulder'-móDa and kənda. MóDa can refer to the side of the shoulder, whereas kənda cannot. So, while it is possible to describe bumping into someone as móDa marna (lit. 'shoulder hit'), it is not possible to say * kənda marna (lit. 'shoulder hit'), indicating that kənda does not refer to the side of the shoulder. Mó Da does not exclusively refer to the side of the shoulder, however, as when things are carried on the shoulder they can be described as moDe te cuk (lit. 'shoulders on carry') or kənde te cuk (lit. 'shoulders on carry'), suggesting that both terms can be used to refer to the shoulder as a whole. 
There is large variation in the extension people give for the terms referring to the back. For example, some speakers have a specific interpretation for lak as the area which curves in: its prototype is probably the lower back and it spreads out to the sides including the waist; but other speakers claim that lək refers to the whole back, from the neck to the base of the spine, and is just the same as TUi, piTTh, kəmər or Tık. The only term for back which has a clearly delineated extension is $m \supset R$, and it refers to the upper back, specifically, the area including the shoulder blades. The variation in extension for terms referring to back is not dissimilar to what Meira reports for Tiriyó (Meira, this volume). TUi which refers to back in this dialect differs from Jelum Punjabi where TUi is an impolite word for 'buttocks' (see Buck, 1949).

The term for armpit, $k ə c$, extends for some speakers down the side of the torso, i.e. the area of the torso which is hidden by the arm when it is against the side of the body. To hold a baby is to hold it kucaR, i.e. 'hold-on-hip' and one consultant thought that the term $k u c a R$ also referred to a body region, that is to the place where the baby rests along the side of the torso, however other consultants did not agree.

The term ark 'elbow' is known only to the older speakers and is not in everyday use; younger speakers only use kũni. Both ərk and kũni refer to the 'elbow joint' and have the same extension.

Both fingers and toes are referred to by Ũygli, but its primary sense is 'finger' and not 'digit'. There is converging evidence to support this interpretation. First, consultants say that there are 10 Ungglia, not 20, as would be expected if the term denotes 'digit' and not 'finger'. Second, although in the appropriate context Ũggli alone could be used to refer to a toe, the more common way to refer to a toe is to use the complex term pær di Ũygli 'foot its finger'. And finally, the 'finger-tip' is Ũygli da p’̀Ta (lit. 'finger its tip'); but the 'tip of the toe' is not Ungli da pjTa, as you would expect if Ungli referred to 'digit', instead the 'tip of the toe' is referred to by pær da pذTa (lit. 'foot its tip').

There is further parallelism between the digits of the hand and feet. Two digits on the hand have simplex terms used to refer to them anGuTha 'thumb' and cici 'little finger'. There are corresponding terms to refer to the feet, namely pær da ənGuTha (lit. 'foot its thumb', 'big toe') and pær di cici (lit. 'foot its little finger'). The term for nail, no, is different from the other terms in that it is general, or underspecified, about whether it refers to the fingernails or toenails. The 'palm' of the hand is talli, alternative forms are tilli and hattheli and the 'sole of the foot' is pær di talli (lit. 'foot its palm').

The term komli occurs in two places, nakk di komli 'tip of the nose' (lit. 'nose its komli'), and kann di komli 'earlobe' (lit. 'ear its komli'). The term komli has to have an inherent possessor (see van Staden, this volume, for a pervasive system of inherent possession of body parts) - it is always possessed by either the nose or the ear. There are two reasons komli is distinct to English tip which can also be found in phrases, or compounds which refer to the body (e.g. fingertip, tip of the nose, tip of the tongue, etc.). One is that tip can be combined creatively with body parts to create new categories (e.g. tip of the chin, tip of the hair, etc.); komli cannot be used to form ad hoc body part categories. The second reason is that tip is used outside the domain of the body (e.g. tip of the pen, tip of the iceberg, etc.), but komli is exclusively used to refer to body parts.

The clitoris is referred to as the phəphóndi danna. It is unclear what phəphóndi means, but danna is used to refer to a single grain of rice, or a single bean, or a single pea. 


\subsection{Internal parts}

There are simplex terms to refer to the major internal organs. A non-monomorphemic term is used to refer to the 'womb'. The womb is the bəcce dani 'child pot'. The term dani is also used in the phrase cha dani 'teapot'. So, the term bəcce dani means something like 'receptacle for child'.

The most striking thing about the Punjabi body lexicon for internal parts, is that there is a term for a body part which does not exist anatomically. The $k_{0} D D i$ is believed to be an organ which is located at the bottom of the sternum. It is said to be about the size of a small egg, and like an egg oval in shape. Consultants also claim that one can feel it on some people - and locate it to the xiphoid process (a small angularly shaped protruding bone located at the bottom of the sternum). So, if the $k_{0} D D i$ has extensional reference, then through touch it is equivalent to the xiphoid process. Note though, that the xiphoid process is not an organ, and thus is not the anatomical correlate to koDDi.

In folk theory the $k_{0} D D i$ can 'drop' or 'fall' out of place, which causes nausea, illness and vomiting. The illness ends when the $k_{o} D D i$ goes back to its rightful place. If a child or woman unexpectedly falls ill, an elder woman will feel the stomach to check whether the illness is due to the $k_{\supset} D D i$ having fallen from its place. If it has then the woman will massage the stomach and sternum area to locate the $k_{o} D D i$. If she concludes that the $k_{o} D D i$ has dropped then it will be restored to its rightful place through vigorous massage of the stomach. Other women may also be involved in the process of checking to see if they can locate the koDDi and to massage it back to its correct location. Frequently, one of the healers will claim to be able to feel the $k_{\supset} D D i$ in its new location, and this will be verified by a second, and even third person. This is additional evidence that the $k_{0} D D i$ is not referentially equivalent to the xiphoid process: the xiphoid process does not move from its place, and yet, the women all agree that they can feel that it has moved. So, there is a collective 'delusion' about its new location that is not accompanied by any perceptual evidence (Bartholomew and Goode, 2001). ${ }^{3}$

The koDDi does not enjoy the same status as other parts of the body in one way: whereas there is an analogical mapping between human parts of the body and animal parts of the body, the $k_{2} D D i$ is believed only to exist in humans (although there were some younger consultants who were not sure whether animals have one or not) (Table 3).

\subsection{Configurational parts}

A number of body part terms in Punjabi describe a hand configuration. Table 4 provides a list of these, with translations and illustrations. Five different terms are used to describe 'fist': four of them are used for the hand configuration when it is used for punching $m U k k a$, hura, ghUssUn and kUsunna. The other fist term muTTh is not appropriate for the action of punching, rather it denotes the hand configuration alone. So, while it is acceptable to say mUkka mar 'punch' (lit. 'fist hit') or ghUssUn mar 'punch' (lit. 'fist hit'), it is not acceptable to say *muTTh mar 'punch' (lit. 'fist hit').

\footnotetext{
${ }^{3}$ P. Brown (personal communication) reports a part of the body in Tzeltal, which appears to be functionally the same as the koDDi. The me'winik ('mother-man') is a part of the body that is believed to be located in the lower abdomen and it monitors health in some way. There is no anatomical correlate for this body part.
} 
Table 3

Punjabi internal parts of the body

\begin{tabular}{|c|c|c|c|}
\hline Punjabi term & Translation & Gender and number & Other information \\
\hline \multicolumn{4}{|l|}{ Simplex } \\
\hline$j i b$ & 'tongue' & $\mathrm{f}$ & \\
\hline tunddua & 'lingual fraenum' & $\mathrm{m}$ & $\begin{array}{l}\text { thin, vertical fold of tissue } \\
\text { between tongue and floor of mouth }\end{array}$ \\
\hline dənd & 'tooth' & $\mathrm{m}$ & \\
\hline$d a R$ & 'molar tooth' & $\mathrm{f}$ & \\
\hline$p i R$ & 'teeth and gums' & $\mathrm{m}$ & \\
\hline masuDaa & 'gum’ & $\mathrm{m}$ & \\
\hline but & 'toothless gum' & $\mathrm{m}$ & \\
\hline$k \tilde{a}$ & 'uvula' & $\mathrm{m}$ & \\
\hline kənDi & 'velum' & $\mathrm{m}$ & \\
\hline tallu & 'palate' & $\mathrm{m}$ & \\
\hline khopRi & 'scalp, skull, mind' & $\mathrm{f}$ & \\
\hline khopRa & 'scalp, skull, mind' & $\mathrm{m}$ & \\
\hline dimag & 'brain, mind' & $\mathrm{m}$ & Hindi-Urdu loan \\
\hline pejja & 'brain' & $\mathrm{m}$ & \\
\hline hallak & 'throat' & $\mathrm{f}$ & \\
\hline gəla & 'throat' & $\mathrm{m}$ & \\
\hline vakkhi & 'rib' & $\mathrm{m}$ & \\
\hline pəsli & 'rib' & $\mathrm{f}$ & \\
\hline gosht & 'flesh, muscle, meat' & $\mathrm{m}$ & \\
\hline mas & 'flesh, fat' & $\mathrm{m}$ & \\
\hline boTi & 'flesh, muscle' & $\mathrm{f}$ & \\
\hline$h_{\partial} D D i$ & 'bone' & $\mathrm{f}$ & \\
\hline əndrã & 'all internal organs' & $\mathrm{f}$ & \\
\hline$o j R i$ & 'guts' & $\mathrm{f}$ & \\
\hline pıphRaa & 'lung' & $\mathrm{m}$ & \\
\hline$d_{\iota} l$ & 'heart' & $\mathrm{m}$ & \\
\hline gordda & 'kidney' & $\mathrm{m}$ & \\
\hline medda & 'stomach' & $\mathrm{m}$ & \\
\hline pittaa & 'gall bladder' & $\mathrm{m}$ & \\
\hline kaleja & 'liver' & $\mathrm{m}$ & \\
\hline Tilli & 'spleen' & $\mathrm{f}$ & \\
\hline$\eta a R$ & 'veins' & f & \\
\hline laú & 'blood' & $\mathrm{m}$ & \\
\hline khũn & 'blood' & $\mathrm{f}$ & Hindi-Urdu loan \\
\hline phoddi & 'female genital area' & & \\
\hline ol & 'placenta' & $\mathrm{f}$ & \\
\hline naf & 'navel (inside)' & $\mathrm{f}$ & \\
\hline$k \supset D D i$ & $\begin{array}{l}\text { 'oval shaped organ located } \\
\text { at the bottom of the sternum' }\end{array}$ & f & No anatomical equivalent \\
\hline mosanne & 'sweat glands, pores' & $\mathrm{m}$ & \\
\hline \multicolumn{4}{|l|}{ Complex } \\
\hline akkəl daR & 'wisdom tooth' & $\mathrm{f}$ & \\
\hline RiR di səngli & 'spine', 'regio vertebralis' & $\mathrm{f}$ & lit. 'back its chain' \\
\hline piTTh di həDDi & 'bone in lower back' & $\mathrm{f}$ & lit. 'back its bone' \\
\hline bəcce dani & 'womb' & $\mathrm{f}$ & lit. 'child's pot' \\
\hline
\end{tabular}

There are two terms to refer to cupped hands: coli refers to a single hand in a cupped position; $b U k$ to the hand configuration when the symmetrical other hand is joined, that is, 
Table 4

Punjabi configuration parts of the body

\begin{tabular}{lll}
\hline Punjabi term & Translation & Gender \\
\hline mUkka & 'fist (for punching)' & $\mathrm{m}$ \\
hura & 'fist (for punching)' & $\mathrm{m}$ \\
ghUssUn & 'fist (for punching)' & $\mathrm{m}$ \\
kUsunna & 'fist (for punching)' & $\mathrm{m}$ \\
muTTh & 'fist' & $\mathrm{f}$
\end{tabular}

cappa 'hand's breadth (measure)'

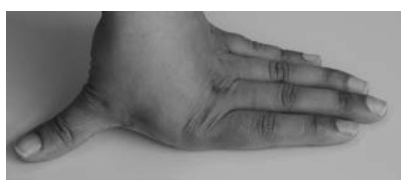

$\mathrm{m}$

bUk 'cupped hands and joining'

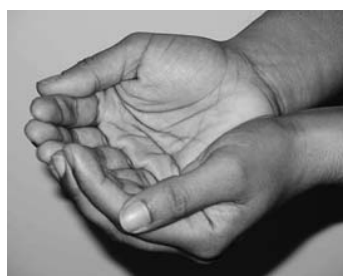

$\mathrm{m}$

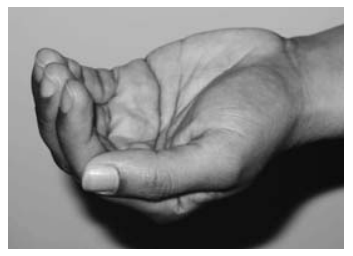

'one cupped hand, lap, a concavity suitable for containment'

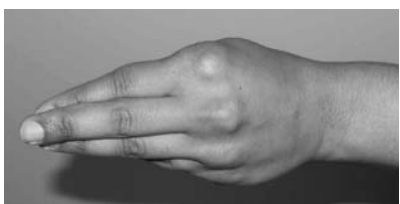

$\mathrm{m}$

guT

'hand with fingers straight and bunched together'

both hands cupped with the sides of the hands from pinkie to wrist touching. BUk refers only to the hand configuration; on the other hand, coli does not just denote a single cupped hand, but has a much broader meaning. It is also the term used for 'lap', and for the shape of a dress or shawl when it is held out from the body. Traditional Punjabi clothes are the səlwar kəmiz (lit. 'trouser tunic') with a cadər 'large shawl' which both men and women wear. Both the kəmiz and cadər can be held out from the body by holding the bottom edge 
of the fabric. If the arms are kept loosely bent at the elbow, so that the fabric is not taughtly held away from the body, it will form a hollow. The hollow is used to carry loose particulate things, such as rice, or beans. This hollow is also called coli. So, the semantics of coli is something akin to 'a concavity suitable for containment'. As evidence for this compare the collocations acceptable for English lap in contrast with Punjabi coli. English lap can refer to both the configuration of the body, which forms a concavity, and it can also refer just to the top of the thighs: an infant can sit in a lap suggesting the body is being construed as a container or on a lap suggesting that the thighs are being construed as a surface for placement of the infant. In Punjabi the postposition vicc 'in' is used for relations of containment and contrasts with utte 'on'/'above' for relations of both 'surface contact' and 'higher than' (cf. Mandarin discussed in Bowerman and Pederson, 1992). In Punjabi only the postposition indicating a containment relation is possible to describe an infant placed on a lap, not the postposition indicating surface contact, as Examples (7) and (8) illustrate.

còli vicc bæTh
lap in sit
'Sit in the lap!'

*(8) còli utte bæTh

lap on sit

'Sit on the lap!'

While the linguistic forms bUk and coli differ in both intension and extension, the corresponding hand configurations also have interesting differences. As well as being used for practical actions, such as cupping water in the hands to drink, the single and dual cupped hands are emblematic gestures, that is, gestures which have conventionalised meaning and standards of well-formedness (Efron, 1941/1972). For example, the 'thumbs up' gesture in America and Britain indicates that everything is okay. The gesture has to be formed with the fingers clenched and the thumb pointing up; if the thumb points down then it indicates something different - that everything is not okay; and if the fingers are not clenched then it is not 'well-formed' and does not carry meaning. Emblems can be insults or praise, but are mostly attempts to control other people's behaviours.

The two emblematic gestures under discussion are "begging gestures": both are used when an appeal for help is being made. The appeal can be for material goods, as when the gestures are used by beggars requesting money, but the gestures can also be used when asking for assistance more generally, as when a neighbour asks an unwilling person for assistance to do some chore. The single cupped hand is used when there is a direct appeal being made to the person; whereas the dual cupped hands are used when the appeal is being made indirectly via God. The dual cupped hands are used during prayer, so appeals using this gesture are mediated through God.

The term for the outstretched fingers bunched together, guT, is the same term as used for the wrist: it is as if the wrist carried on projecting out from the arm, and did not end at the hand joint. This hand position is assumed for measuring what size of bangle a woman needs. Punjabi women adorn their wrists with brightly coloured glass bangles. The more tightly fitted the bangle is around the wrist the more attractive it is deemed to be. However, the constraint on getting the bangle on the arm is the circumference of the hand when assuming the 
configuration in Table 4. The width of the hand at the knuckles when extending the fingers in the guT configuration constrains the size of the bangle that can be worn.

Finally, cappa is used both to refer to a 'hand span', and is used as a unit of measurement (see also Enfield, this volume b).

\subsection{Bodily products and other parts}

Table 5 is a list of terms which are in the semantic domain of the body, but which consultants did not accept as parts of the body. There was complete agreement among all consultants of all age-groups that none of these terms were parts of the body, although they all accepted that these were related to the body, e.g. they were things that the body produced. The term for 'soul' $r u$ is not given in the table as consultants neither accepted it as a body part, nor accepted it as related to the body domain. It was considered a different kind of thing altogether: the $r u$ is incorporeal, while the body is corporeal, so consultants claimed that the ru cannot be a part of the body.

Table 5

Punjabi bodily products

\begin{tabular}{llll}
\hline Punjabi term & Translation & $\begin{array}{l}\text { Gender and } \\
\text { number }\end{array}$ & Other information \\
\hline Simplex & & & \\
dəm & 'breath' & $\mathrm{m}$ & \\
sa & 'breath' & $\mathrm{m}$ & Hindi-Urdu loan \\
sans & 'breath' & $\mathrm{m}$ & \\
$b i$ & 'semen' & $\mathrm{f}$ & \\
ləb & 'spittle' & $\mathrm{m}$ & \\
thUk & 'spittle' & $\mathrm{f}$ & \\
pak & 'pus' & $\mathrm{f}$ & \\
jijju & 'a bogey' & $\mathrm{m}$ & combined sexual fluids \\
sinD & 'snot' & $\mathrm{m}$ & \\
libda & 'snot' & $\mathrm{m}$ & \\
kəggaR & 'catarrh' & $\mathrm{m}$ & \\
monni & 'sexual discharge' & $\mathrm{f}$ & \\
& & & \\
resha & 'catarrh, pus' & $\mathrm{m}$ & \\
pitt & 'bile' & $\mathrm{m}$ & \\
pəshab & 'urine' & $\mathrm{m}$ & \\
TəTi & 'faeces' & $\mathrm{f}$ & \\
pəsina & 'sweat' & $\mathrm{m}$ & \\
morkka & 'sweat' & $\mathrm{m}$ & \\
kapre & 'menses' & & \\
mahavari & 'menses' & $\mathrm{f}$ & \\
hæz & 'menses' & & \\
ulTi & 'vomit' & $\mathrm{f}$ & \\
phoRa & 'boil' & $\mathrm{m}$ & \\
coRiã & 'wrinkles' & $\mathrm{f}$ & \\
jala & 'vernix' & pl & \\
Complex & & & \\
kann di mæl & 'ear wax' & & \\
\hline & & $\mathrm{f}$ & \\
\hline
\end{tabular}


Table 6

Punjabi additional body parts for animals

\begin{tabular}{|c|c|c|c|}
\hline Punjabi term & Translation & Gender and number & Other information \\
\hline khall & 'skin of animal' & $\mathrm{m}$ & \\
\hline pınja & 'foot of bird' & $\mathrm{m}$ & \\
\hline $\operatorname{sing}$ & 'horns' & $\mathrm{m}$ & \\
\hline pucc & 'tail' & $\mathrm{m}$ & \\
\hline khoR & 'feet' & $\mathrm{m}$ & \\
\hline than & 'teat' & $\mathrm{f}$ & \\
\hline leva & 'udder' & $\mathrm{m}$ & \\
\hline un & 'wool' & $\mathrm{f}$ & \\
\hline cunj & 'beak' & $\mathrm{f}$ & \\
\hline pər & 'wings' & $\mathrm{m}$ & \\
\hline khəmb & 'feathers' & $\mathrm{m}$ & \\
\hline pәnjja & 'claw' & $\mathrm{m}$ & \\
\hline$k ə n D D a$ & 'quills of porcupine' & $\mathrm{m}$ & \\
\hline su & 'vulva of cow' & $\mathrm{f}$ & \\
\hline $\operatorname{sun} D$ & 'trunk of elephant' & $\mathrm{f}$ & \\
\hline
\end{tabular}

\subsection{Animal parts}

The terms used to refer to human parts of the body are also used to refer to animal parts of the body (with, perhaps, the exception of the $k_{\supset} D D i$ ). Table 6 lists additional terms which are either names for parts of the body which humans do not have, e.g. sıgg 'horns', pucc 'tail', kənDDa 'quills'; or they are terms for parts of the body where there is a possible analogue term from the human body part vocabulary, but a distinction is made nonetheless. For example, cəmRa 'skin' could be used to refer to animal skin, but instead khəll 'animal skin' is used. Similarly, pær 'foot' could be used to refer to the foot of an animal, but some animals, like birds (pinja 'foot of a bird') and cows (khoR 'foot of a cow') have unique foot terms.

\section{Semantic properties}

As discussed in introduction to this volume (Enfield et al., this volume), there are at least two different theories about how people conceptualise the relationship between body part terms. The first is the partonomic view which holds that body part terms are hierarchically related to one another through part-whole relations, so that for example, a nail is a part-of the finger, the finger is a part-of the hand, the hand is a part-of the arm, and the arm is a part-of the body (see Cruse, 1986, 2004). The second is the locative view where body part terms are related to one another through spatial relations, such as in, on, attached-to etc., so that a nail is on the finger, the finger is attached to the arm, and so forth (see Palmer and Nicodemus, 1985).

Punjabi speakers appear to conceptualise some body parts as being related through a part-whole relation, and yet others through a locative relation. This poses a problem for universals of body partonomies proposed by Brown (1976) and Andersen (1978), who claim that ALL body part terms in all languages have a hierarchical structure with no more than six levels. 


\subsection{Where is there partonomy?}

Punjabi speakers accept that all the terms in Tables 1-3 can be felicitously described as being parts of the body in answer to the question:

$\begin{array}{lll}X \quad \text { jism da } & \text { hissa va? } \\ \mathrm{X} \text { body gen.m.sg } & \text { part is } \\ \text { 'Is X a part of the body?' } & \end{array}$

The same frame can be used to establish whether there is a part-whole relationship between other parts of the body. Using this criteria, participants only accept the following body parts as being in a part-whole relationship: Dolla 'upper arm' and væni 'forearm' are parts of bãã 'arm'; paT 'upper leg' and pınni 'lower leg' are parts of lətt 'leg'. It is interesting to note here that Punjabi speakers do not accept the hand as being part of the arm, nor the foot as being part of the leg. A separate study using the 'body colouring task' (van Staden and Majid, this volume), which asked participants to colour in parts of the body, showed independent evidence for this: when asked to colour in the arm and leg on an outline of a human body, participants did not colour in the hand or the foot, respectively. No other body part terms were accepted as being in a part-whole relationship with each other.

If we were to use this test in order to construct a partonomy of the body, then we would have a hierarchy with three levels. The body would be on Level 1, DJlla 'upper arm', væni 'forearm' paT 'upper leg' and pınni 'lower leg' would be on Level 3, and all the rest of the body part lexicon would be on the intermediate Level 2, as shown in Fig. 1.

Although this hierarchy is consistent with the Andersen (1978) and Brown (1976) claims that no language has more than six levels in the body part hierarchy, it does not appear to be a very impressive hierarchy, as it has only one term on Level 1, four terms on Level 3 and 143 terms on Level 2.

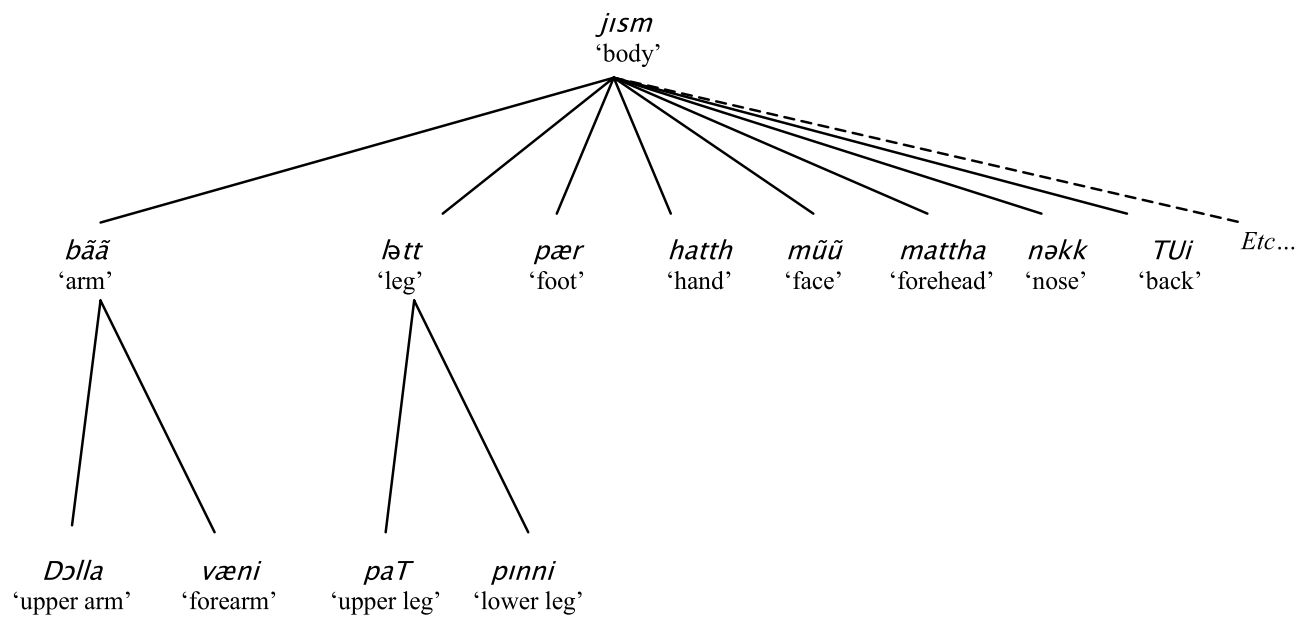

Fig. 1. Hierarchy of body part terms in Punjabi. 
A second way to create a partonomic hierarchy is to establish which parts of the body stand in a possessed-by relationship (Brown, 1976). Brown equates the possessed-by relationship with the part-whole relationship, but these are clearly distinct (see Palmer and Nicodemus, 1985; Enfield et al., this volume). Brown advocates using the genitive construction in order to construct a hierarchy of body part terms. In Punjabi most complex body parts are referred to using the genitive construction. For example, the tip of the nose and the ear lobe are referred to as nakk di komli (lit. 'nose its komli') and kann di komli (lit. 'ear its komli') respectively. More generally, the genitive construction is used when there is potential ambiguity of referent. So, for Ũggli 'digit', əฤGuTha 'thumb', cici 'little finger' and no 'nail', all of which could designate a number of different parts, the genitive construction is used to disambiguate, e.g. pær da əワGuTha 'foot its thumb', versus hath da ə刀GuTha 'hand its thumb'; or oワGuTha da no 'thumb its nail', versus cici da no 'finger its nail'. When consultants were asked if the possessed item was part of the possessor using question-frame (4) (e.g. 'is the nail part of the finger?'), consultants did not readily agree, and were perplexed by the question. This suggests that the genitive construction in Punjabi is not encoding a part-whole relationship.

When consultants were asked whether body part terms were immediately possessed by jısm 'body' using the genitive construction (9) they all rejected this. This poses a problem for constructing a hierarchy of body part terms using the relation of possession as there is no superordinate level, or "unique beginner", i.e. there is no Level 1.

$\begin{array}{lll}\text { *(9) } & \text { jısm } \quad \text { di } & \text { bãã } \\ \text { body gen.f.sg arm } \\ \text { 'the body's arm' ('lit. body its arm') }\end{array}$

\subsection{And when there is no partonomy...}

The majority of terms in Punjabi are not conceptualised as standing in a partonomic relation; instead they are conceptualised as being in a locative relationship: the eyes are in the face (10); the nose is on the face (11); the ears are near the face (12), and so on. It is unclear to what extent these locative relationships are culturally or linguistically codified and to what extent they are just read off a mental representation of the physical body.

əkkha mũu de $\quad$ vicc va
eyes face gen.m.pl in
'The eyes are in the face'

$\begin{array}{llll}\text { (11) nəkk mũu de } & \text { utte va } \\ \text { nose face } & \text { gen.m.pl on is }\end{array}$

'The nose is on the face'

(12) kann mũũ de nal va

ears face gen.m.pl near are

'The ears are near the face' 
Note that only some body parts can be construed as grounds with respect to which other body parts are located. For example, speakers do not accept the following statements:

akkha jısm de vicc/utte/nal va
eyes body gen.m.pl in/on/near are
'The eyes are in/on/near the body'

akkha sır de vicc/utte/nal va
eyes head gen.m.pl in/on/near are
'The eyes are in/on/near the head'

The fact that mũũ 'face' can be treated as a ground for akkha 'eyes' and nəkk 'nose' may suggest a covert hierarchy between these terms, such that mũũ 'face' dominates əkkha 'eyes' and nəkk 'nose'. But, such a covert hierarchy is not well-supported. One reason for this is that the dominance relation between terms in such a hierarchy would not be the same. While the eyes are in the face, the nose is on the face, and so the relationship between eyes and face is not the same as the relationship between nose and face. Similarly, the relationship between sister nodes in the hierarchy, like akkha 'eyes' and nəkk 'nose' would not be the same. Furthermore, it does not seem to be possible to have an indefinitely long chain of links between body part terms (another criteria for hierarchies, Cruse, 1986), instead there is only one chain in the link - that connecting the figure to the ground.

Going back to the locative relations, an interesting cross-linguistic question arises: to what extent do languages share the same conceptualisation of the locative relationship between body parts? It seems that there may be some variation between languages in this respect: while in Punjabi the eyes are conceptualised as being on the face; in Coeur d'Alene they are in the face (Palmer and Nicodemus, 1985).

To summarise, previous researchers have proposed that the relationship between parts of the body is hierarchical, with body parts being parts of other body parts; or that the relationship between parts is more like the spatial relationship between objects, with body parts being in, on, or near other body parts. Punjabi data suggests that both types of conceptualisations exist side by side: a small set of body parts are conceptualised as forming part-whole relations, namely the limbs; while most other body parts are conceptualised as being in a locative relation.

\section{Conclusion}

Body part terms in Punjabi largely correspond to those of the metalanguage English: major divisions such as that between head, neck, upper and lower limbs seem to correspond quite well with English. It is a matter of further investigation to establish how well the boundaries match as well. For example, Punjabi speakers do not accept that the hand is part of the arm, or that the foot is a part of the leg; but it is unclear whether this is true of English too.

Comparison of Punjabi to other languages in this volume, on the other hand, suggests that there may be considerable variability in body part categorisation. Languages differ in how finely body part terms are categorised. Just comparing terms to refer to 'arm' and 
'leg', for example, Lavukaleve (Terrill, this volume) does not distinguish 'arm' and 'leg'; instead there is just one category tau 'limb'; Jahai (Burenhult, this volume) also does not have a linguistic category 'leg' or 'arm' and instead makes a fine-grained distinction of $b l i \vec{l}$ ' 'upper leg', gor 'lower leg', blin 'upper arm' prber 'lower arm'. Punjabi uses a mixture of strategies in naming the limbs, using simplex terms for 'arm' (bãã) and 'leg' (latt) as well as 'upper arm' (Dslla), 'lower arm' (væni), 'upper leg' (paT), and 'lower leg' (pınni).

More generally, Punjabi has a number of categories which are quite unusual in comparison to other languages in this volume. For example, the 'tip of the nose' (nakk di komli) and the earlobe (kann di komli) form a category $(k o m / i)$. This is an unusual category in that it can only be used for these parts of the body, and is not used outside of the domain of the human body. Similarly, there are a number of terms used to refer to various configurations of the hand, which are important in various cultural practices, such as body adornment. And more intriguingly, there is a category of an internal body part which has no anatomical correlate $(k J D D i)$.

Turning to the relationship between parts of the body, speakers of Punjabi agree that there is a partonomy between a very limited set of body parts. The body is the overarching term at Level 1, and sub-parts of arm and leg are at Level 3, with the remaining 144 terms on Level 2. The remainder of terms are said to be in a locative relationship with respect to other body parts, being either 'in', 'on', 'near' or 'attached-to'. Contrary to previous literature (e.g. McClure, 1975; Brown, 1976; Andersen, 1978), construction of partonomies in many languages appears to be problematic (see other contributions to this volume).

The data suggest that if a language is to have a partonomy for body parts, then it would be for the major segments of the body, such as the limbs, but not say for parts of the face, or parts of the torso. This would be consistent with the Punjabi data, as well as other data in this volume (e.g. Levinson, this volume), and fits with previous proposals. So, we would not expect a language to have a partonomic conception of the face alone, without also having such a conception for the limbs. On the other hand, there is suggestive evidence that locative relationships between body parts may perhaps be more variable. For example, speakers of Punjabi and Coeur d'Alene differ in how the eyes are located with respect to the face.

To summarise, there is intriguing variation between Punjabi and other languages in both what body part categories are recognised and how they are related to one another.

\section{Acknowledgments}

Fieldwork was supported by the Max Planck Society. Thanks to Niclas Burenhult, Nick Enfield, and two anonymous reviewers for invaluable comments on an earlier draft.

\section{Appendix A}

Slightly adapted version of Bhatia (1993); examples are transcribed according to the following conventions: 


\begin{tabular}{|c|c|c|c|c|c|}
\hline \multicolumn{6}{|l|}{ Consonants } \\
\hline & labial & dental & retroflex & palatal & velar and glottal (back) \\
\hline $\begin{array}{c}\text { stop, voiceless, } \\
\text { unaspirated }\end{array}$ & $\mathrm{p}$ & $\mathrm{t}$ & $\mathrm{T}$ & c & $\mathrm{k}(\mathrm{q})$ \\
\hline $\begin{array}{l}\text { stop, voiceless, } \\
\text { aspirated }\end{array}$ & ph & th & Th & $\mathrm{ch}$ & $\mathrm{kh}$ \\
\hline $\begin{array}{l}\text { stop, voiced, } \\
\text { unaspirated }\end{array}$ & $b$ & $d$ & $\mathrm{D}$ & $\mathrm{j}$ & g \\
\hline nasal & $\mathrm{m}$ & $\mathrm{n}$ & $\mathrm{N}$ & $\tilde{\mathrm{n}}$ & $\eta$ \\
\hline flap & & r & $\mathrm{R}$ & & \\
\hline lateral & & I & $\mathrm{L}$ & & \\
\hline fricative, voiceless & $\mathrm{s}$ & sh & & & $\times h$ \\
\hline fricative, voiced & z & & & & G \\
\hline semivowel & $w(v)$ & & & & $\mathrm{y}$ \\
\hline
\end{tabular}

\begin{tabular}{llll}
\hline Vowels & & & \\
\hline & front & central & back \\
\hline High (tense) & $\mathrm{I}$ & & $\mathrm{u}$ \\
High (lax) & $\mathrm{e}$ & & $\mathrm{U}$ \\
Mid high & $æ$ & ə & o \\
Mid low & $\sim$ & $\mathrm{a}$ & \\
Low & & & \\
Vowel nasalisation & & & \\
& & & \\
\hline Tone & & & \\
\hline High & & & \\
Mid & & & \\
Low & & & \\
\hline
\end{tabular}

\section{Appendix B}

\section{Glossary of terms}

3 third person

erg ergative case

gen genitive case

pl plural number

sg singular number

$\mathrm{m}$ masculine

f feminine 


\section{References}

Andersen, E.S., 1978. Lexical universals of body-part terminology. In: Greenberg, J.H. (Ed.), Universals of Human Language, vol. 3. Stanford University Press, Stanford, pp. 335-368.

Bartholomew, R.E., Goode, E., 2001. Little Green Men, Meowing Nuns and Head-Hunting Panics: A Study of Mass Psychogenic Illnesses and Social Delusion. McFarland and Co, Jefferson.

Bhatia, T.K., 1993. Punjabi: A Cognitive-Descriptive Grammar. Routledge, London.

Bowerman, M., Pederson, E., 1992. Cross-linguistic perspectives on topological spatial relations. In: American Anthropological Association Annual Meeting, San Francisco.

Brown, C.H., 1976. General principles of human anatomical partonomy and speculations on the growth of partonomic nomenclature. American Ethnologist 3, 400-424.

Brown, C.H., Witkowski, S.R., 1981. Figurative language in a universalist perspective. American Ethnologist 8 , 596-615.

Brown, R., 1958. How shall a thing be called? Psychological Review 65, 14-21.

Buck, C.D., 1949. A Dictionary of Selected Synonyms in the Principal Indo-European Languages: A Contribution to the History of Ideas. Chicago University Press, Chicago.

Burenhult, N., this volume. Body part terms in Jahai. In: Majid, A., Enfield, N.J., van Staden, M. (Eds.), Parts of the Body: Cross-Linguistic Categorisation (Special Issue). Language Sciences, doi:10.1016/ j.langsci.2005.11.002.

Cruse, D.A., 1986. Lexical Semantics. Cambridge University Press, Cambridge.

Cruse, A., 2004. Meaning in Language: An Introduction to Semantics and Pragmatics. Oxford University Press, Oxford.

Efron, D., 1941/1972. Gesture, Race and Culture. Mouton, The Hague.

Enfield, N.J., this volume a. Elicitation guide on parts of the body. In: Majid, A., Enfield, N.J., van Staden, M. (Eds.), Parts of the Body: Cross-Linguistic Categorisation (Special Issue). Language Sciences, doi:10.1016/ j.langsci.2005.11.003.

Enfield, N.J., this volume b. Lao body part terms. In: Majid, A., Enfield, N.J., van Staden, M. (Eds.), Parts of the Body: Cross-Linguistic Categorisation (Special Issue). Language Sciences, doi:10.1016/j.langsci.2005.11.011.

Enfield, N.J., Majid, A., van Staden, M., this volume. Cross-linguistic categorisation of the body: Introduction. In: Majid, A., Enfield, N.J., van Staden, M. (Eds.), Parts of the Body: Cross-Linguistic Categorisation (Special Issue). Language Sciences, doi:10.1016/j.langsci.2005.11.001.

Grierson, G.A., 1916/1968. Linguistic Survey of India. Motilal Banarsidass, Delhi.

Levinson, S.C., this volume. Parts of the body in Yélî Dnye, the Papuan language of Rossel Island. In: Majid, A., Enfield, N.J., van Staden, M. (Eds.), Parts of the Body: Cross-Linguistic Categorisation (Special Issue). Language Sciences, doi:10.1016/j.langsci.2005.11.007.

McClure, E.F., 1975. Ethno-anatomy: the structure of the domain. Anthropological Linguistics 17, $78-88$.

Meira, S., this volume. Tiriyó body part terms. In: Majid, A., Enfield, N.J., van Staden, M. (Eds.), Parts of the Body: Cross-Linguistic Categorisation (Special Issue). Language Sciences, doi:10.1016/j.langsci.2005.11.009.

Palmer, G.B., Nicodemus, L., 1985. Coeur d'Alene exceptions to proposed universals of anatomical nomenclature. American Ethnologist 12, 341-359.

Ruff, C., 2002. Variation in human body size and shape. Annual Review of Anthropology 31, 211-232.

Terrill, A., this volume. Body part terms in Lavukaleve, a Papuan language of the Solomon Islands. In: Majid, A., Enfield, N.J., van Staden, M. (Eds.), Parts of the Body: Cross-Linguistic Categorisation (Special Issue). Language Sciences, doi:10.1016/j.langsci.2005.11.008.

Tolstaya, N.I., 1981. The Punjabi Language: A Descriptive Grammar. Routledge and Kegan Paul, London. van Staden, M., this volume. The body and its parts in Tidore, a Papuan language of Eastern Indonesia. In: Majid, A., Enfield, N.J., van Staden, M. (Eds.), Parts of the Body: Cross-Linguistic Categorisation (Special Issue). Language Sciences, doi:10.1016/j.langsci.2005.11.013.

van Staden, M., Majid, A., this volume. Body colouring task. In: Majid, A., Enfield, N.J., van Staden, M. (Eds.), Parts of the Body: Cross-Linguistic Categorisation (Special Issue). Language Sciences, doi:10.1016/ j.langsci.2005.11.004.

Wilkins, D.P., 1996. Natural tendencies of semantic change and the search for cognates. In: Durie, M., Ross, M. (Eds.), The Comparative Method Reviewed. Oxford University Press, Oxford, pp. 264-304. 